\title{
Pollen and seed morphology of Justicieae (Ruellioideae, Acanthaceae) of Yemen
}

\begin{abstract}
Pollen and seeds of 12 genera and 28 species belonging to Justicieae namely, Anisotes, Angkalanthus, Asystasia, Ballochia, Dicliptera, Ecbolium, Hypoestes, Isoglossa, Justicia, Megalochlamys, Rhinacanthus and Trichocalyx were collected from different field localities in Yemen and were investigated using both light and scanning electron microscopes. Nine pollen types were observed whose shapes were prolate, subprolate and spheroidal while the apertures varied from dicolporate, tricolporate, porate to colpate. The exine ornamentation was reticulate in most of the species except Megalochlamyas, which showed perforate ornamentation, and Isoglossa, which showed reticulate to rugulate ornamentation. Scanning electron microscopy and morphological observations showed that mature dry seeds of the genera have various sizes and shapes, the surface ornamentations observed were reticulate, cristate, tuberculate and papillae. In addition, hairs were present in some Ballochia species. The variation in the seed structures between the genera and within the species was useful for their identification and classification; their high structural diversity is of important taxonomic value for species differentiation.
\end{abstract}

Keyword: Arabia; Palynology; Seed surface; Taxonomy 